\title{
THE IDENTIFICATION OF VILLAGE AND TOURISM POTENTIALS IN FACING ECONOMIC SOCIAL THREATS OF COMMUNITIES IN PEATLAND
}

\author{
Ashaluddin Jalil (1), Yesi (2 *), Seger Sugiyanto (3) \\ ${ }^{123}$ Department of Sociology, FISIP, Universitas Riau, Riau, Indonesia.
}

\section{ARTICLE INFORMATION

$\begin{array}{ll}\text { Submitted } & : 29^{\text {th }} \text { April } 2021 \\ \text { Review } & : 01^{\text {st }} \text { October } 2021 \\ \text { Accepted } & : 06^{\text {th }} \text { December } 2021 \\ \text { Published } & : 18^{\text {th }} \text { December } 2021 \\ \text { Available Online : December 2021. }\end{array}$

\section{KEYWORDS}

Village Potential; Peat Land; Forest and Land Fires

\section{CORRESPONDENCE}

*E-mail: yesi.y@lecturer.unri.ac.id

\begin{abstract}
A B S T R A C T
Vulnerability to the forest and land fires in the Tohor River began in 2007 and 2009 due to the construction of canals for village development as well as the canalization of sago companies, which are 5-7 meters wide. The purpose of the study identified potential resources for people's lives and peatland protection. Data collection using observations, interviews, and discussion forums. The results showed that the potential in the field of natural resources consists of plantations including sago, rubber, river fisheries, honey, and natural forest vegetation. In addition, the economic potential is also very large individuals and groups have implemented the management of sago derivative products such as sago sugar, sago noodles, sago rendang, sago amplang, and various handicrafts from sago such as rumbia roofs, bags and mats. In the field of human resources, there are LPMP village institutions, PKK and KKP, Environmentally Conscious Group, Tohor River Youth, Fish Farming Group, and community network including sago farming groups and youth associations. The productive age group is also quite large but they generally work a lot in Malaysia as contract workers. The potential of Natural Resources and Human Resources is important in people's lives especially to protect peat but the potential has not been developed to the maximum. Collaboration from stakeholders is required to develop optimally the potential available for better peat life and ecosystem.
\end{abstract}

\section{A. INTRODUCTION}

$\mathrm{n}$ general, it can be said that Riau is an area that is very vulnerable to forest and land fires. Almost all regions have this experience because the majority have peatlands, including the Tohor River. Forest and land fires that occurred in the Tohor River in 2014, which at that time scorched about 183 thousand hectares of land, if pulled back, the symptoms of drought have started since the government built canals in 2007. Road construction and various facilities could not done on a stretch of free peat, so that as a method on the left and right side, a canal is built so that part of the area becomes dry to build facilities such as roads and so on.

The canalization ends in the sea, so when the high season arrives, the entry of sea water into peat is inevitable. The canal is only 2 meters wide, so the salt water has killed the thatch trees on the edge of the canal. This situation was exacerbated in 2009, PT. LUM which is a company that owns acacia plantation concessions builds large canals 5-7 meters wide. This method clearly exacerbates the situation, land that is not included in the concession area also experiences drought as a result of being sucked up by the canals made by the company.

As a result of this drying, the farmers suffered a big loss, the thatch trees and other plants they hoped for their daily needs died, they could not be harvested like before the drought. In addition, a situation that is more severe is that people find it difficult to get clean water for household needs, some people dig up to tens of meters to get water and some are displaced with neighbors who still have water in their wells and for people. the rich they are willing to buy water for 30 thousand per derigen.

The sad story above is a chronology of the drought that occurred in the Tohor River until it reached its peak when there was a severe fire in 2014. At that time, more than 250 hectares of land were burned with allegations that the fire originated from plantation activities carried out by PT. NSP. The 
fire burned down a lot of plants and productive land of the community, not only that the impact of smoke was also felt by residents in Malaysia and Singapore. This incident then prompted a resident to create a petition signed by more than 23 thousand people and made President Jokowi go down to Sungai Tohor for the first time to inspect the fire location.

The portrait in the field shows that the community faces social and economic threats in the form of tenure conflicts with plantation companies and the internal community and low income so that many of the Tohor River residents choose to work abroad such as working in Malaysia. This is not only experienced by parents but it is sad that the productive age that should be maximally utilized to develop the potential of the village actually also works abroad.

The difficulties to obtain employment in villages, the lack of knowledge in managing peat ecosystems, and the lack of capital are some of the reasons that work mobility occurs continuously. Based on the data issued by the Selat Panjang Immigration Office in 2019 which had issued 9,780 passports with several destinations including at most Malaysia(Wir, 2020). Many people who choose to work abroad will have an impact on the lack of interest to be involved in managing the existing potential, including becoming a farmer. Whereas the Tohor River has a lot of potential and has even been used as an international laboratory of tropical peat which means that there will be many people from various parts of the world, start from researchers and those who just want an educational tour to visit the Tohor River.

Potential identification is part of efforts to provide alternative sources of livelihood based on local wisdom. That is, through the identified potential there will be other livelihood alternatives that are more varied and sustainable. This is important because socioeconomic problems are fundamental problems that should be addressed by mapping out what potential they can exploit. Especially to reduce the mobility of the people of the Tohor River to work abroad. The potential role of the region in relation to social life makes an important contribution to improving the economy better. Using a sociological approach, we mapped the potential of both Natural Resources and Human Resources to unravel and address socio-economic issues such as poverty, employment and helplessness.

The potential in the Tohor River is also a wish for a better economic level. It should be carried out education and learning about good peat ecosystem management so that community interest arises to manage it (Goib et al., 2019). However, this effort must also be supported by various stakeholders(Winarno et al., 2019), both local communities, formal leaders and companies that are nearby.

The company also needs to provide support in developing the potential of the Tohor River community because of the existing threats and various problems if traced to their plantation activities such as canalization or drainage of peatlands before planting.
The purpose of this study is to identify the potential that exists in the Tohor River community both Natural Resources and Human Resources that can be utilized to overcome various threats and social problems(Leifeld \& Menichetti, 2018), especially in the community economy and peat ecosystem sustainability(Handoko et al., 2020).

We often hear the word social threat which can also be said to be a social problem because it causes inconvenience and public unrest. The social problems are different from other problems because of their close relationship with institutions and norms, the social problems are considered problems because they involve human relations and values that are a distraction to the expectations of society or things that are deemed necessary in terms of morals(Rahman, 2011). The term of social problems is closely related to an unwanted event which means it can be a threat to society socially, economically, culturally and disintegration. Based on the standpoint of social science that the social problems arise due to the process of social change and cultural change. Both of these are social processes that will be experienced by people with the different time frames. The emergence of social problems because there is something lacking from human beings or social groups that originates from economic, biological, biopsychological, and cultural factors(Nasution, 2004). The social welfare problems that exist in society tend to increase and develop with the emergence of the new social problems and the conventional problems that are directly related to the social problems which certainly affect various aspects of life. Some of them include the social disintegration, the social discrimination, the social inequality, the national cultural value systems that can support life, welfare and so on(Haruswati et al., 2012). At the end of the day we convey that the purpose of this research and writing is to convey a picture of socio-economic problems that occur at the study site as well as mapping the potential that can be used as a way to overcome these problems.

\section{B. METHOD}

$\mathrm{T}$ he research method was to obtain data in accordance with the research objectives, the authors conducted interviews and forum group discussions (FGD) to the community and local leaders. We conducted interviews with 7 informants from the local community both formal figures and other community leaders. In addition, the author also makes direct observations and traces through a variety of existing literature studies from various sources. The techniques of data analysis carried out in a descriptive qualitative intended to dismantle research problems by linking them to the patterns of activity, situations and conditions, as well as the subjective meaning of each informant that is the source of the data(Leavy, 2017). In addition to qualitative the author also integrates it with the analysis of Harvard methods which include activities, 
access, participation, awareness and control as well as factors that influence(Apriyono \& Pitoyo, 2014).

\section{RESULTS AND DISCUSSION}

L iving in peatlands is a challenge for the people of Sungai Tohor. Managing peatlands is not as easy as turning the palm of your hand. The extra sacrifice is needed so that peat can be processed for a variety of commodities both in the plantation sector, fisheries, and other sectors. They live in a big threat related to the environmental crisis in the future which will directly target welfare issues (Winarno et al., 2019). The threats are something that has not yet happened but it has the opportunity to become a big problem when the community is unable to create alternatives to overcome the threat. Threats can also be said to be a problem that unwanted nature, the intrusive, the difficult to tolerate (Murni, 2014), and the require of the steps to overcome them.

The threat to the community in Sungai Tohor Village is very real. The land that is no longer what it used to be is a form of this real threat. Since the drainage effort occurred by building canalization in 2007 by the government as a land transportation route, it has become critical. However, this effort must be done like it or not so that the transportation routes or the community access become easier, especially for traveling outside the village. But, after the construction was finished there were symptoms of drought and the difficulty in getting clean water, besides that some agricultural commodities began to develop poorly. This clearly has an impact on the income of farmers who have decreased especially those who are very dependent on agricultural output at the time.

This situation continued, which became even more dire because around the Tohor River there were also the plantation companies. In 2009 alone, The company of LUM Ltd. conducts canalization of 5-9 meters which makes the community's land drier due to peat water being thrown freely into the sea. Not to mention the activities of NSP Ltd. also built a canalization of plantations that caused fires in 2014. The canalization seems to be the only option for draining peat. If this is done for infrastructure development may not be going to be a big problem because it would be difficult for people to move in on the wet turf. However, if drying is carried out for the purpose of clearing new plantations, it becomes a problem because they tend not to play around in doing the drainage which consequently makes the land drier.

The sustainable management of peatlands besides requiring knowledge also requires the large capital. Although the community is treated with alternatives to clearing land safely through a no-burn system, in fact this is also a dilemma. One side of the land will be safe, but on the other hand the community requires a relatively longer time.
The land clearing system without burning is echoed along with the restoration carried out in the peat area. In Sungai Tohor Village, the restoration efforts have been carried out since 2017 through the rewetting, the revegetation and the revitalization scheme. The wetting is arranged in such a way that the land remains in good humidity through the construction of canal blocking or monitoring wells. This effort is accompanied by replanting of local wood or other plants that have economic value which is also safe if cultivated on peatlands. Finally, the aspect touched on is about the economy of the community. The new alternative livelihoods that are environmentally friendly and the sustainable are provided.

However, once again that social problems faced by real threats involving the parties of super power so it will be difficult to solve problems. In the case of sago development, for example, the Tohor community faces threats from the existence of two HTI companies (PT. NSP and PT. Lestari Unggul Makmur who have large plantations and enter community plantation lands. They also usually face land management with canalization and land clearing that severely impedes plantation progress of sago from the aspect of physical land.

For issues of tenure conflict like this it takes a very hard effort to keep the community from experiencing severe impacts from their activities. However, at least the community must have their own efforts in dealing with these threats, namely by involving various kinds of parties in order to manage the existing potential to be used as a source of income and ensure welfare. The stimulation to the community for new livelihoods and the new technology will create resilience in any condition even if at any time critical land and drought occur, they already have alternative anticipatory steps. In addition to social problems in the form of tenure conflicts, the next issue which is a problem is community welfare. The issue of community welfare is a fundamental problem, marked by the large number of people who choose to work abroad because they find it difficult to find work in the village. This is also a problem where the most appropriate answer is through developing local potential by involving various parties.

\section{The Potential of Sungai Tohor Village}

Endowed with peat swamps Sungai Tohor Village has a lot of potential that can be developed as a solution in dealing with various threats both to environmental sustainability and threats to the welfare of the community. The identification of village potential in this study will be mapped into two, namely the potential of natural resources and the potential relating to human resources. 


\section{a. The Potential Natural Resources of Sungai Tohor Village}

More recently the name River into the limelight Tohor nationwide for holding events of the prestigious festival sago. The event held on March 13 until 15, 2020 , presented a number of important figures with the agenda of consolidating various parties in an effort to conserve sago as a leading commodity in peatlands in a sustainable manner. Do not forget that the event also held an exhibition of local products made from sago.

The peat and the sago are two inseparable things. In Sungai Tohor Village, the sago is indeed the favourite of the community. The sago has become the economic pillar of the community that is not only promising but also safe for cultivation on peatlands. The sago potential is huge because it can be processed into a substitute for rice which is very safe for consumption.

The planting sago is not difficult, which becomes difficult is waiting for the first harvest. The local farmers say that to get good sago for the first time they have to wait between 8 until 10 years.

"A good sago takes around 8 until 10 years if the time is right the quality of the sago will be good apart from being influenced by the land and its maintenance. Taking care of it is not difficult at all. The first 3 years must be diligently cared for during the day and other cleaning, but do not go through the clean-up, it is not good, the bottom is a bit where the trash is placed so that it is moist" (Interview with the sago farmer).

The great potential of sago must be balanced with maximum care so that sago can grow well and can produce superior tual quality.

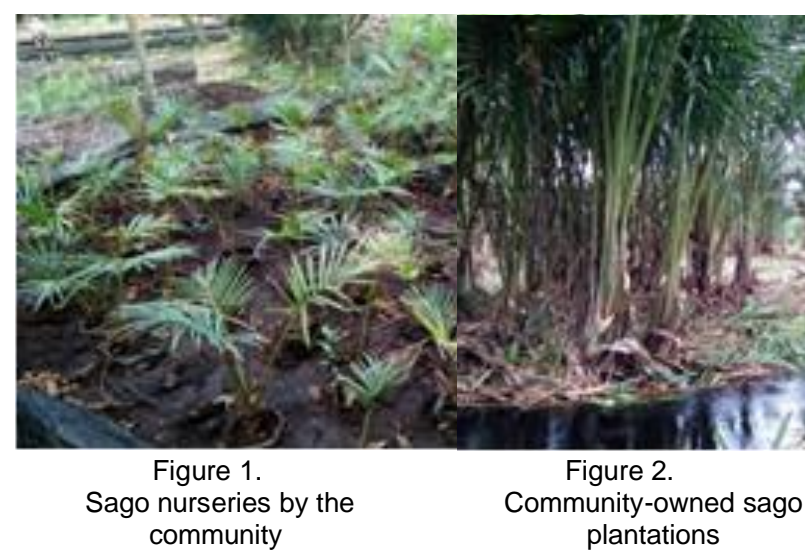

If the sago is not treated in the first years between 1 until 3 years according to the local community it will be easily devoured by pests and will have stunted growth. The community also does not need to bother buying seeds because they can be developed by themselves as some farmers in the Tohor River do. It was intended to minimize the cost of planting and could be diverted for maintenance costs. However, aside from having to take care, the people who cultivate sago should prepare alternative livelihoods while waiting for harvest sago. Most people of Sungai Tohor also carry out other activities on their land such as growing palawija, planting areca nut, and other commodities with relatively faster harvest time. Based on data accessed from the monograph of Sungai Tohor Village in 2018, the following writer presents a recapitulation of the area of land used for farming.

\section{Table 1.}

\begin{tabular}{clr}
\multicolumn{3}{c}{ The Plantation Area Based on Commodities } \\
\hline No & Plantation type & Area (Ha) \\
\hline 1 & The Sago & 2650 \\
2 & The Rubber & 1320 \\
3 & The betel nut & 4 \\
4 & The Coconut & 2 \\
\hline
\end{tabular}

Source: Monographs of Sungai Tohor Village, 2019.

The capacity of the potential of sago development is not only in cotton area, on the river Tohor itself until now, there are 17 refineries sago (although not entirely inactive) process tual sago into raw materials which are then exported to others territory including Malaysia.

The tual sago that has been harvested by farmers usually will first be soaked in the river if the garden accesses the distant refinery and or is brought to the refinery via the river transportation in parallel. The community said that the price of sago tual was also determined by the harvest period and the final quality of the sago harvested. Some choices can be made by people who plant sago to sell their crops which consist of selling directly to sago refineries and processing their own sago which is harvested at the refinery, and both have different price details. 
sago by itself at the refinery by paying rent of Rp. 120,000 to Rp. 230,000 involving around 15 workers with a wage of Rp. 110,000 with the owner's profit around 650 tons per day because in one process the refinery produces up to 36 tons(Amady, 2017).

The seriousness of the government in developing the sago commodity in Sungai Tohor Village can be seen with the construction of an integrated sago processing centre which will soon be inaugu rated. This development is certainly a breath of fresh air for the local community, especially farmers who have sago gardens.

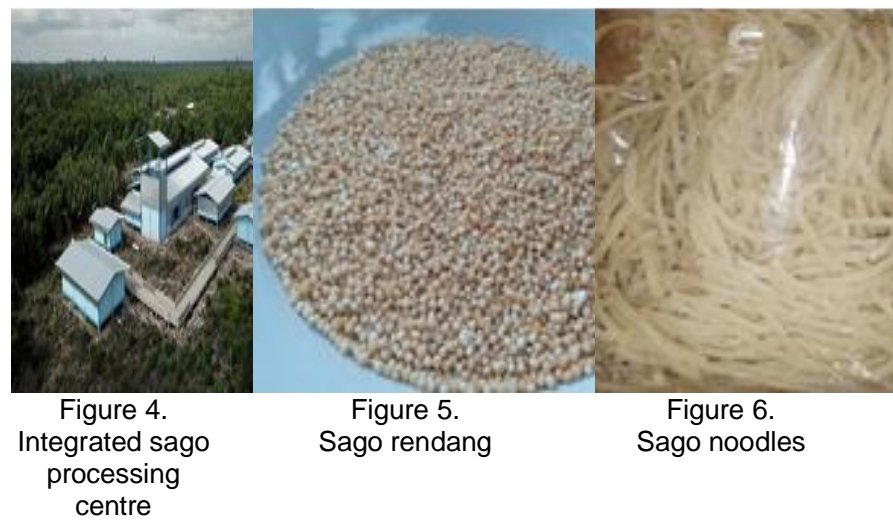

The development of supporting infrastructure in the development of the sago industry is a continuing effort in the food sector. The sago is a source of carbohydrate as a substitute for rice which is loved by many people and can be processed into anything. Some processed products produced from sago include sago rendang, sago noodles, sago peyek, ongol-ongol, sago crackers, sago brownies, and other processed products. Not only is it a food product, other parts of sago namely leave and petioles can be used by the community to be used as the thatch roof and shack floor, or other handicrafts.

Moreover, with the development of infrastructure, the future of dried sago processing does not need to be exported, or can be processed by the local community. Besides having the potential in the field of sago plantations, another potential in Sungai Tohor Village is the rubber with an area of around 1,320 hectares. The average community in addition to having a sago plantation they also have a rubber plantation both on their own land specifically and planted behind their homes.

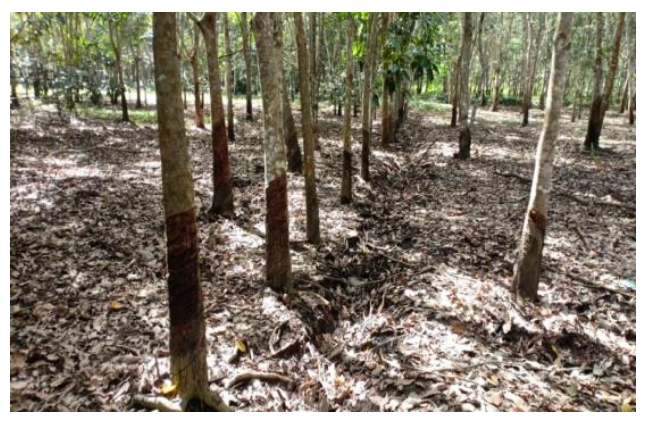

Figure 7.

The condition of rubber plantation owned by the community
However, the rubber is a commodity whose price is changed and volatile. In addition to price, the weather also plays a role in the productivity of the rubber. Although in Sungai Tohor village, the rubber plantations are also quite extensive, but for the farmers, they often complain of relatively little profit, especially if the production is also low, so the profit is only enough for the cost of living for a few days. The sales of leads are made through Toke. At this Toke level, there are price cuts both for the transportation wages and other deductions so that the price received by the farmers is only around $\mathrm{Rp} 5,000$ to $\mathrm{Rp} 7,000$.

If in the normal conditions, they can sell the results leads more than $100 \mathrm{~kg}$ in the once stood. But since a few times, it has been very difficult to gather so much the rubber especially when the rainy season arrives. The communities who truly depend on their livelihoods from the rubber plantations do not have other side jobs during famine they will be in debt to Toke to make a living.

The rubber has indeed become a potential plantation in Sungai Tohor Village after sago. However, the rubber is not used like the sago. One reason is because the economic value produced by the rubber is still below the sago and the level of productivity tends to go up and down. In the end, the people who cultivate of the rubber plants in their gardens need to be educated on how to do good rubber farming at least to guarantee the minimum needs of their household. This is considered necessary by considering various kinds of risks that arise from rubber farming which turns out to be more than sago.

Not only stop there, another local potential that is very likely to be developed is Kelulut honey. In Sungai Tohor Village, The Kelulut honey began to be developed on a small scale per person. There is no cultivation in groups because the results of the honey Kelulut not yet seen clearly.

However, if this is carried out properly and can be an alternative livelihood for a relatively safe community because its management does not use fire. The management model can be modelled after Tanjung Sari Village, which has already produced and developed The Kelulut honey products. The results have also been sold in various regions both directly and through online.

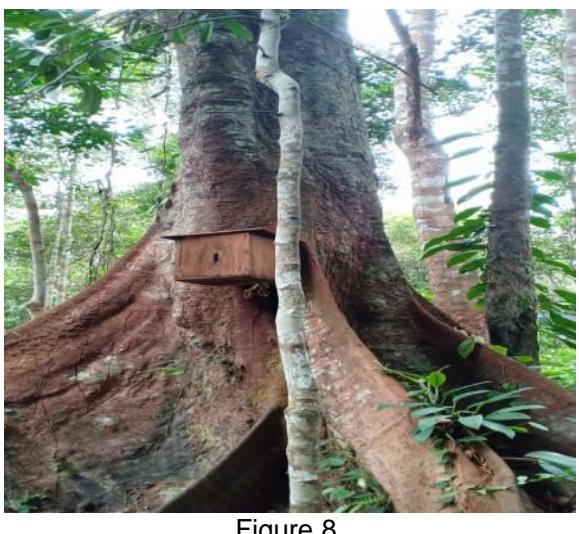

Trial cultivation of kelulut honey by the community 
The cultivation of Kelulut honey can also be a side income for the community. For example, for those who farm sago, while waiting for sago to be harvested, they can cultivate Kelulut honey for alternative sources of income. The next potential that can also be used as a safe source of income for the community is the river. Although there are not many people who become fishermen, this work also has the potential to increase income. The catches do not need to be sold outside the village because to meet the community's demand, Sungai Tohor village is sometimes still lacking.

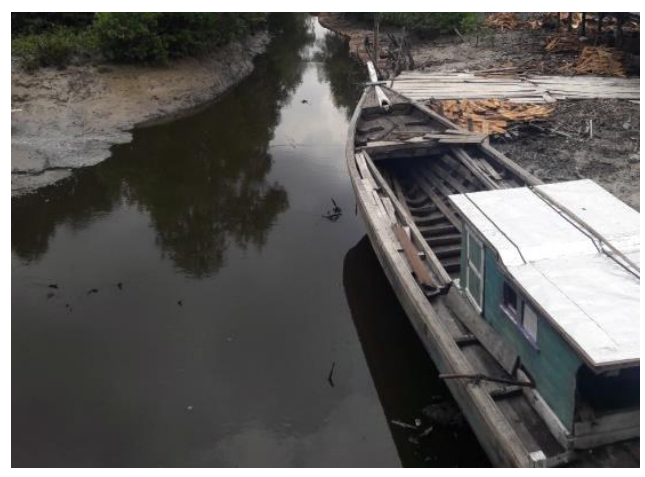

Figure 9.

River flow that can be utilized by fishermen

The fishermen can fish or catch fish in the sea and along the river flow. No need to fish some other catches are also popular by the community such as mangrove crabs. Potential in the field of fisheries is actually not only in the utilization of rivers, local peat swamp fish farming can also be done either by making ponds or utilizing village canals as shown below.

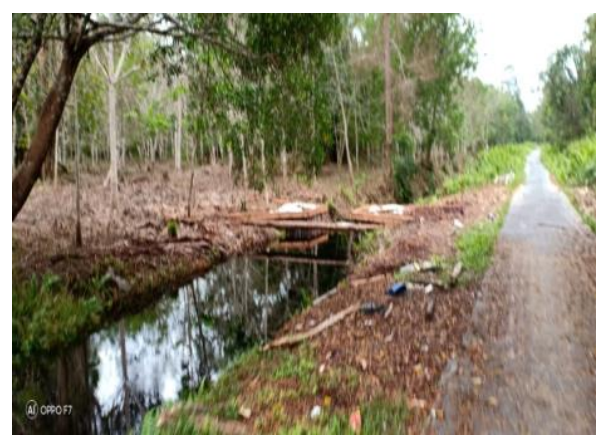

Figure 10

Sungai Tohor Village Canal

In peat, the fisheries sector can also be developed at home scale or through group-based management. The commodities can also be adjusted to taste and those that have the possibility to live and can develop in peatlands such as tuakang fish and lele fish as local catfish. Making cultivation media can use the materials that are environmentally friendly and easily available anywhere so that people do not feel burdened to look for material when they want to start their own business. If this is done with careful planning, it will have a good impact on the community itself, in addition to improving the household economy, the community is also easy to adopt in their respective homes or private land (Jalil et al., 2019).

Sungai Tohor Village does have extraordinary peat charm. The prospect of sustainability is very visible with so much the natural potential. This potential also strengthens, it as an interna tional tropical peat research laboratory that will pre sent a specificity for anyone visiting this village. If the development is carried out continuously by taking into account the existing potential, the Tohor River can be an example for other regions that have the same problems related to peat ecosystems.

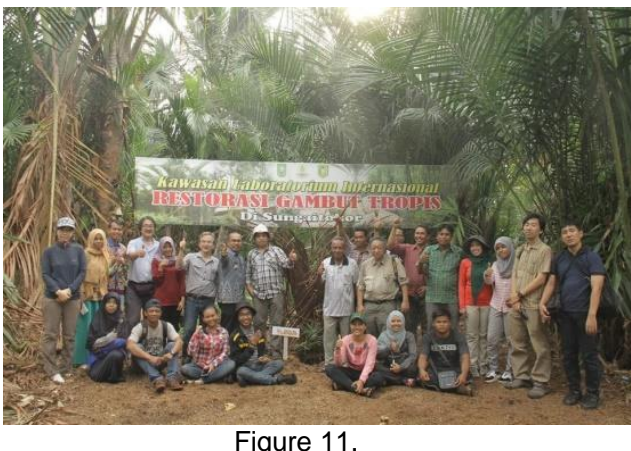

Photo session with visitors and researchers at the Tohor River tropical peat international laboratory area

The results of existing research can also be used as a policy reference for stakeholders to maintain and maintain the sustainability of the peat ecosystem to a better standard of living while continuing to promote environmental aspects.

\section{b. The Potential of Human Resources in Sungai Tohor Village}

The potential of human resources in Sungai Tohor Village can also be said to be diverse, start from the population of productive age to social institutions. The potential of human resources is equally important to get special attention because it is directly related to the regularity of society and various kinds of problems if not managed properly.

\section{The Productive Age of Population}

The potential of human resources can be seen from the productive age group shown in the table below:

Table 2.

Total Population Based on Age

\begin{tabular}{clc}
\hline No & Age group & Amount \\
\hline 1 & $0-5$ years & 139 \\
2 & $5-10$ years & 128 \\
3 & $11-17$ years old & 166 \\
4 & 18 -36 years old & 237 \\
5 & 36 years and above & 402 \\
& Total Amount & $\mathbf{1 , 0 7 2}$ \\
\hline \multicolumn{2}{c}{ Source: Monographs of Sungai Tohor Village, 2019. }
\end{tabular}

ASHALUDDIN JALIL, DKK 
If referring to the table above, the composition of the population of Sungai Tohor Village is dominated at the age of 36 years and over. The producti ve age group in Sungai Tohor Village reaches almost $50 \%$ of the total population. However, it is unfortunate that the majority of these age groups do work mobility to neighbouring countries such as Malaysia to try their luck.

They chose to work outside the agricultural sector and outside the village, because according to them the expectation of working outside was greater than in the village. The findings also indicate that a decline in interest groups age young to be a farmer so that this generation of farmers is relatively low impact. The agricultural sector is an attractive and promising sector if it is managed diligently and seriously. But in its development, regeneration is also needed to ensure the sustainability of the sector in the future. The development of the potential of productive age groups can be done in line with the potential of existing natural resources. If done together, at least all the potentials will be well managed. One side of the natural potential is increasingly providing maximum benefits to the community, on the other hand this is also a form of providing employment in the village.

The assumption that finding work in a difficult village is actually more due to their ignorance in managing the existing potential and the lack of capital. This issue of capital and knowledge must be a priority to be overcome considering working abroad does not provide a definite guarantee for their lives. If at any time in a famine condition then termination of employment occurs while he does not have savings in the village for example in the form of a garden then it will cause its own problems. So the education about peatland governance and its various potentials needs to be carried out sustainably as a stimulus for productive age groups to be interested in participating in developing village potential. Do not forget the planning regarding upstream-downstream development potential also must be done carefully, for example who will help them to develop that potential, where they get capital from, and where they will sell their crops if they are not developed by local agricultural products.

\section{The Social of Institution}

The next potential is the social institutions. The social of institutions in relation to community life certainly have a purpose and are bound by norms. The social of institutions in Sungai Tohor Village have a strategic function in maintaining security from a variety of threats and social problems that exist.
Table 3.

\section{The Identification of the Social Institution of Sungai Tohor Village}

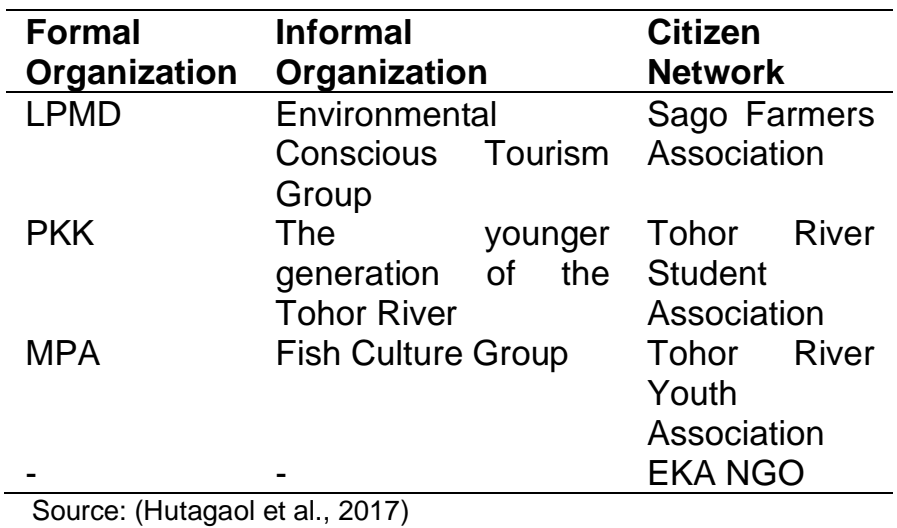

In terms of social institutions, it can be seen that the Tohor River has many institutional organizations, both formal, informal and involving community networks. They have their respective roles in protecting peat ecosystems and the community survival. The appropriate institutional schemes involving many young people to participate. This also becomes its own strength in creating order and efforts to fulfil needs, especially in economic matters, for example by the existence of a fish farming group and a group of sago farmers. Through this group, various kinds of problems can be overcome by involving elements in the Tohor river community. The existing of social institutions also need to be provided with various educational and coaching programs in order to increase the capacity and capabilities of each. The orovisions like this also need to be given so that institutions are not merely ceremonial and can bring change to the community and face various existing problems. We believe that this mapping can be useful and contribute to solving social problems that occur at the study site and in the scientific world contributes to the study of the sociology of tourism.

\section{CONCLUSIONS}

$\mathrm{B}$ ased on the identification of the existing potential, the Tohor River has diverse natural potentials and overall can be said to be friendly to peat ecosystems and does not pose a threat to sustainable peat governance. The potential identification can be described as follows: a) The potential natural resources consist of peat recreation and education tours, the sago plantations, the rubber plantations, the processed of sago products, the local fisheries, and Kelulut honey; b) The potential human resources comprises informal institutions including the Environmental Awareness Tourism Group, the Tohor River Youth Generation, and the Fish Cultivation Group, and community networks including the Sago Farmers Association, the Tohor River Student Student Association and the Tohor River Youth 
Association. Another potential human resource is the productive age group that reaches almost $50 \%$ of the total population.

\section{E. ACKNOWLEDGMENT}

W e would like to thank the editor of the Journal of Anthropology: Socio-Cultural Issues (Jantro) for better writing input in scriptwriting. We would also like to thank the Peat Restoration Agency for the restoration efforts in The Tohor River as well as to the Riau University Disaster Studies Center for information support. This research is supported by DIPA funding of Riau University.

\section{REFERENCES}

Amady, M. R. El. (2017). Jaminan Konsumsi Rumah Tangga Petani Sagu di Desa Sungai Tohor Kabupaten Meranti Riau. Umbara: Indonesian Journal of Anthropology, 2(2), 88-96. https://doi.org/DOI: https://doi.org/10.24198/umbara.v2i2.20448

Apriyono, T., \& Pitoyo, A. J. (2014). Identifikasi Potensi Desa sebagai Dasar Pengembangan Desa Wisata di Desa Wukirsari Kecamatan Imogiri Kabupaten Bantul. Bumi Indonesia, 3(4), 1-9. http://lib.geo.ugm.ac.id/ojs/index.php/jbi/article/view/668/641

Goib, B. K., Fitriani, N., Wicaksono, S. A., Yazid, M., \& Adriani, D. (2019). Livelihood Revitalization in Peatlands: Woven Crafts From Purun As A Sustainable Business Option in Ogan Komering llir (OKI) Regency South Sumatra. Analisis Kebijakan Kehutanan, 16(1), 67-87. https://doi.org/: http://dx.doi.org/10.20886/jakk.2019.16.1.67-87

Handoko, T., Tinov, T., Febrian, A. F., Putri, R. A., Andini, F. K., \& Rifansyah, O. (2020). Peatlands Restoration As A Potential Solution To Resolve Peatlands Damage Based On Sustainable Development Goals (SDGS) In SungaiTohor, Indonesia. Nira, 13(1), 123-131. https://doi.org/https:// doi.org/10.31849/niara.v13i1.3876

Haruswati, I., Suhendi, A., Roebyantho, H., Mujiyadi, B., Widodo, N., \& Sumarno, S. (2012). Studi Kebutuhan dan Evaluasi Program Pembangunan Kesejahteraan Sosial di Indonesia. P3KS Press.

Hutagaol, J., Erizal, \& Kamari, A. (2017). Desa Peduli Gambut Provinsi Riau Desa Sungai Tohor. Badan Restorasi Gambut Republik Indonesia. https://www.google.com/search?q=Desa+Peduli+ Gambu+Provinsi+Riau+Desa+Sungai+Tohor\&oq=Desa+Peduli+Gambu+Provinsi+Riau+Desa+Sungai +Tohor\&aqs=chrome..69i57j0i333.757j0j9\&sourceid=chrome\&ie=UTF-8

Jalil, A., Yesi, \& Sugiyanto, S. (2019). The Restoration Effort Of Peat Moss Ecosystem Postconflagration Of The Forest And The Land In Lukun Village Of Tebing Tinggi Timur Regency. Antropologi: Isu-Isu Sosial Budaya, 21(1), 103-110. https://doi.org/https://doi.org/10.25077/ jantro.v21.n1.p103-110.2019

Leavy, P. (2017). Research Design: Quantitative, Qualitative, Mixed Methods, Art-Based, and CommunityBased Participatory Research Approaches. The Guilford Press.

Leifeld, J., \& Menichetti, L. (2018). The underappreciated potential of peatlands in global climate change mitigation strategies. Nature Communications, 9(1071), 1-7. https://doi.org/DOI: 10.1038/s41467-01803406-6

Murni, R. (2014). Sumber Daya dan Permasalahan Sosial di Daerah Tertinggal: Kasus Desa Patoameme Kabupaten Boalemo. Sosio Konsepsia, 4(1), 260-273. https://doi.org/https://doi.org/ 10.33007/ska.v4i1.108

Nasution, M. (2004). Peranan Hukum dalam Penyelesaian Masalah-Masalah Sosial. USU Digital Library. http://repository.usu.ac.id/handle/123456789/1523

Rahman, M. T. (2011). Glosari Teori Sosial. Ibnu Sina Press.

Winarno, B., Rohadi, D., Herawati, T., Rahmat, M., \& Suwarno, E. (2019). Out of fire disaster: dynamics of livelihood strategies of rural community on peatland use and management. IOP Conf. Series: Earth and Environmental Science 487, 1-10. https://doi.org/doi:10.1088/1755-1315/487/1/012008

Wir. (2020). 2019, Imigrasi Selatpanjang Terbitkan 9.780 Paspor. Riaupos.Jawapos.Com. 2019, Imigrasi Selatpanjang Terbitkan 9.780 Paspor 